\title{
PENERAPAN DALIL SYAR'I : UPAYA MENCIPTAKAN LINGKUNGAN KERJA RAMAH MANUSIA
}

\author{
Muhammad Farid \\ UIN Syarif Hidayatullah Jakarta, Indonesia \\ E-mail: Sajajapra@gmail.com
}

\begin{abstract}
The difference between causal about gender and its practice makes problems related to economy, welfare and education more prominent. The majority understands that gender is an equal right between men and women. Such understanding is what erodes the role as well as the inner degree of a woman. This condition can be seen in the current work environment which increasingly alienates women from their families. So that the work environment that should be a factor driving the economy becomes a new problem because of its inferiority towards women and children. Islam as a religion of mercy for all nature provides solutions and enlightenment related to the problem. With the application of the arguments syar'i (Islamic law) is expected to all run accordingly. So that balance and satisfaction will be achieved by all parties. In this paper describes a good work environment from an Islamic perspective, namely a work environment that is friendly to children, women and the company itself.
\end{abstract}

Keywords: women; child; Islam and work environment

Abstrak. Adanya perbedaan antara kausal tentang gender dan praktiknya membuat masalah-masalah terkait dengan ekonomi, kesejahteraan dan pendidikan semakin mencuat. Mayoritas memahami bahwa gender merupakan persamaan hak antara laki-laki dan perempuan secara penuh. Pemahaman seperti itulah yang sejatinya menggerus peran sekaligus derajat bathiniah seorang wanita. Kondisi tersebut dapat dilihat pada lingkungan kerja kekinian yang semakin menjauhkan perempuan dengan keluarganya. Sehingga lingkungan kerja yang seharusnya menjadi faktor pendorong ekonomi justru menjadi masalah baru sebab ketidak ramahannya terhadap perempuan dan anak. Islam sebagai agama rahmat bagi seluruh alam memberikan solusi dan pencerahan terkait masalah tersebut. Dengan penerapan dalil-dalil syar'i (hukum islam) diharapkan semua berjalan semestinya. Sehingga keseimbangan dan kepuasan akan dicapai oleh semua pihak. Dalam paper ini menjelaskan tentang lingkungan kerja yang baik perspektif islam, yaitu lingkungan kerja yang ramah anak, perempuan dan perusahaan itu sendiri.

Kata Kunci: perempuan; anak; Islam dan lingkungan kerja

Permalink/DOI: https://doi.org/10.15408/harkat.v14i2.12821 


\section{Pendahuluan}

Dewasa ini mayoritas orang mulai berfikir dan ragu terhadap ajaran islam. Banyak yang menafsirkan ajaran islam tak lagi relevan dengan situasi dan kondisi kekinian. Kebanyakan dari tafsiran islam yang ada tidak pas dan tidak kontekstual dengan kondisi dan semangat zaman. Sementara manusia hidup dan berkesadaran sesuai dengan kondisi dan pola pikir zamannya.Akhirnya, banyak dari masyarakat maupun perusahaan lebih memilih konsep pemikiran barat yang cenderung mengandalkan rasio dan profit semata.

Masalah yang timbul kemudian yaitu kesulitan yang tidak diinginkan perlahan mulai menjamur. Tak terkecuali pada bidang ekonomi yang merambah kepada kondisi keluarga, pendidikan, dan masa depan seorang anak yang tidak terarah. Jika diruntut akar masalahnya maka kita akan menemukan ada pemaknaan yang salah dalam memahami konsep kesetaraan gender. Mengapa demikian?

Sebab, kosep gender yang di telan mentah justru akan menimbulkan penurunan harga diri dan peran wanita sebagai makhluk yang istimewa. Wanita selalu menjadi topik yang menarik untuk dikaji eksistensinya, karakteristiknya, maupun problematikanya. Berkaitan dengan gender, banyak pekerjaan yang dulu tidak bisa atau tidak boleh dilakukan oleh wanita sekarang lazim dikerjakan olehnya. Kebutuhan akan tenaga kerja akibat perkembangan sosial perekonomian, menyebabkan wanita terjun ke lapangan kerja.(M. Nur Ghufron, 2013:112)

Kondisi tersebut secara nilai ekonomis merupakan peluang bagi suatu perusahaan maupun negara. Sebab, yang mulanya suatu pekerjaan hanya boleh dikerjakan oleh lelaki sekarang boleh juga dilakukan oleh wanita, jadi tenaga kerja lebih berlimpah. Demikian juga berbagai jenis jabatan baru yang tidak tergantung pada jenis kelamin tertentu, menyediakan peluang bagi perempuan.

Perusahaan-perusahaan multinasional melanggengkan steretiotip gender, sebagian melalui iklan. Mereka juga mengekalkan gagasan bahwa kulur utara, kultur kulit putih, merupakan tujuan akhir bagi perkembangan bertahap semua kultur lainnya. Hal itu, menurut Suhadi (2010) termasuk misi kolonialisme dan imperalisme dalam menjajah kembali dunia. Dengan itu Barat memang menampakkan penghormatannya terhadap wanita, membebaskannya dari kedzaliman laki-laki, suami, dan semisalnya. Akan tetapi perempuan di barat sesungguhnya hanyalah dihormati secara lahiriah, sedangkan lahiriah mereka terhina (Suhadi, 2010: 44).

Sebab, demikian daripada itu membuat banyak wanita yang bekerja diluar rumah. Artinya, wanita tidak hanya menjadi ibu rumah tangga namun juga berkarir.Implikasinya, peran perempuan (ibu) sebagai pendidik anak-anak dan penentram keluargaakan semakin tergerus. Padahal telah jelas disebutkan dalam pasal 45 UUP bahwa suami dan istri wajib memelihara dan mendidik anak-anak sebaik-baiknya sampai dapat berdiri sendiri atau kawin. (Supriyadi, 2015: 40)

Sebelum itu, dalam penelitian Mufatihatut Taubah, (2010:154) hak anak untuk memperoleh kebutuhan ASI (bagi BATITA) dan kasih sayang dari ibunya akan berkurang. Padahal dalam Al-Quran dijelaskan dalam surat Al-Baqoroh ayat 233.

"Para ibu hendaknya menyusui anaknya selama dua tahun penuh, yaitu bagi yang ingin menyempurnakan penyusuannya...” (QS. AlBaqoroh : 233)

Kondisi seperti ini harus diimbangi dengan penerapan lingkungan kerja yang sesuai dengan syariah islam. Seperti yang telah dijelaskan Korkut Ozal (2009) mengutip surat 
kenegaraan Ali bin Abi Thalibtentang prinsipprinsip kepemimpinan dan organisasi dalam islam. Yaitu dengan tidak mendiskriminasi hak antar pekerja, memberi ruang gerak yang terbuka, mendengarkan keluh kesah pekerja, dan memudahkan urusan mereka. Hal tersebut juga bisa direalisasikan dalam bentuk penyediaan ruang dan waktu menyusui, memberikan santunan kesehatan bagi wanita hamil sampai melahirkan. Dan segala yang berkaitan dengan keharmonisan keluarga pekerja (UU. No. 13 Tahun 2003 tentang Ketenagakerjaan).

Penafsiran islam yang sesuai dengan semangat zaman sangatlah diperlukan agar keraguan pola pikir yang sedang menjalar bisa segera terobati. Implikasinya, ajaran islam akan semakin relevan dan menjadi pegangan bagi masyarakat ditengah gelombang kehidupan modern.

Penerapan syari'ah islam dalam kehidupan sehari-hari nantinya juga akan membawa kebahagiaan dan keseimbangan pada semua lini. Sebab, seperti yang banyak disebutkan bahwa islam adalah agama pemberi rahmat bagi seluruh alam (rahmatan lil 'alamin).

Adanya pembahasan ini diharapkan akan memberi pencerahan kepada masyarakat utamanya yang bergelut dalam dunia bisnis bidang personalia supaya memahami betul konteks gender yang sesuai dengan syariah islam.

\section{Pembahasan}

\section{Dalil Syar'i tentang Wanita dalam Keluarga}

Sebagaimana telah kita ketahui, bahwa islam adalah agama yang mengatur segaloa kebutuhan pemeluknya dengan sebaik dan senyaman mungkin. Oleh sebab itulah islam disebut sebagai agama rahmat bagi seluruh alam (rahmatan lil álamin). Termasuk di dalamnya, islam juga membahas tentang wanita, bahkan pembahasannya mendetail sampai-sampai dalam
Al-Qur'an dijadikan nama surat (An-Nisa'). Sebagai bukti bahwa wanita dalam islam sangatlah dihargai dan dimuliakan. Eksistensi wanita dimata islam juga tidak dipandang sebelah mata(Abu Syuqqoh, 1996: 14). Derajatnya dalam beramal saleh disamakan dengan laki-laki, sebagaimana dalam surat AnNisa' ayat 124 ,

"Barang siapa yang mengerjakan amal saleh, baik laki-laki maupun perempuan sedang ia orang beriman maka mereka itu akan masuk kedalam syurga" (QS. An-Nisa' : 124)

Namun, ada peran khusus yang diatur islam terkait wanita dalam keluarga. Yaitu supaya wanita menjadi sosok pengatur ketentraman.Dalam upaya menjaga keluarga sakinah, manusia baik laki-laki maupun perempuan yang telah menjalin hubungan pernikahan dituntut untuk saling menumbuhkan kasih sayang. Seperti yang dijelaskan dalam Al-Qur'an, potongan ayat 23 surat Asy-Syuraa :

"Aku tidak meminta kepadamu sesuatu upah pun atas seruanku, kecuali kasih sayang dalam keluargamu.” (QS. Asy-Syuraa : 23)

Menurut Mufatihatut Taubah (2010: 152), kebahagiaan yang seperti demikian akan lebih sempurna jika dihiasi oleh gelak tawa, canda gurau si buah hati belahan jiwa pelipur lara, penerus generasi bangsa dan agama yang shalih dan shalihah, sehat jasmani dan rohani. Dalam hal ini anak menjadi kunci kebahagiaan dan kesejahteraan bagi setiap insan yang berkeluarga. Anak merupakan amanat Allah ditangan orang tuanya.

Untuk mewujudkan generasi yang diharapkan peran ibu sangatlah dibutuhkan. Karena seorang wanita merupakan sosok figur dan individu yang mempunyai potensi dalam membina keluarga yang sehat dan sejahtera. Di tangan ibu lah masa depan anak akan dipertaruhkan, apakah kelah dia akan menjadi 
seorang yang bermanfaat bagi agama dan bangsanya. Dengan budi pekerti yang baik ataukah sebaliknya. Maka dari itu dibutuhkan kesadaran akan pentingnya peran seorang ibu dalam perkembangan dan pertumbuhan anak (Mufatihatut Taubah, $2010: 153$ ).

Salah satu cara merealisasikan kasih sayang itu ialah dengan cara memberikan ASI terhadap bayinya. Sebagaimana orang dewasa, bayi membutuhkan makanan yang mengandung vitamin, protein, kalori dan mineral (Desmita, 2013: 97). Bagi bayi berusia 4-6 bulan pertama ASI merupakan sumber energi yang utama. Sebab, memberi ASI berarti memberi susu yang bersih dan dapat dicerna serta menolong mengimunisasi bayi yang baru lahir dari penyakit. Hal ini juga diterangkan dalam islam, tepatnya pada surat Al-Qashshash ayat 7,

"Dan Kami ilhamkan kepada ibu Musa, "Susukanlah dia”." (QS. Al-Qashshash : 7)

Dalam konteks ayat lain dalam Al-Qur'an, pemberian ASI justru dianjurkan eksklusif selama 2 tahun.

"Para ibu hendaklah menyusui anaknya selama dua tahun penuh, yaitu bagi yang ingin menyempurnakan penyusuannya..." (QS. AlBaqarah : 233)

Islam sangat menganjurkan pemberian ASI ini sebab hal itu merupakan refleksi kasih sayang, ketaatan dan wujud syukur seorang wanita terhadap anugerah Allah SWT berupa anak. Itulah sebabnya walaupun islam mengizinkan wanita bergerak di masyarakat sesuai keperluannya, namun tetap memandang bahwa perannya sebagai seorang ibu jauh lebih penting.

Bahkan menurut Coleman, (1976) alasan pemberian ASI ini dalam berbagai penelitian terbukti bahwa hal itu sangat mempengaruhi intelektual, mental, sosial bahkan fisik anak(Coleman, 1976 : 152-156).
Begitulah sejatinya tujuan dari diciptakannya sosok perempuan. Konsep kesetaraan gender tidak seharusnya menjadi ancaman bagi perempuan sehingga terhina bathinnya, seperti yang terjadi di dunia barat. Islam memandang gender sebagai penyamaan derajat untuk sama-sama memperoleh hak pendidikan, dan pelayanan sehingga bisa menjalankan perannya dengan baik.

Dengan begitu, kejahatan yang sering memakan korban perempuan akan berkurang. Juga kemuliaan perempuan juga akan senantiasa terjaga. Implikasi dari hal itu masalah keluarga, kemiskinan, pendidikan akan mudah teratasi. Generasi-generasi emas pun akan melimpah demi mewujudkan negeri yang diharapkan semua pihak, yang baik dan senantiasa mendapat pengampunan dari Tuhan (baldatun tayyibatun wa rabbun ghafur).

\section{Kebijakan Perusahaan Perspektif Islam}

Suatu perusahaan dalam menjalankan usahanya haruslah mempunyai manajemen yang baik demi kelanggengan dan kemajuan bersama. hal itu menjadi penting sebab perusahaan masuk dalam lingkup penggerak ekonomi. Adanya perusahaan akan tercipta perputaran uang yang bisa menjadikan keberlangsungan hidup masyarakat tatap seimbang. Terkait dengan manajemen ada beberapa hal yang perlu dikaji demi terciptanya kehidupan yang diharapkan. Salah satu yang menjadi pembahasan penting yaitu pada kebijakan suatu perusahaan dalam menciptakan lingkungan kerja yang baik bagi semua pihak.

Hal ini menjadi penting sebab didalamnya mengaitkan banyak manusia (masyarakat). Lebih dari itu, hal ini juga menyangkut masa depan suatu bangsa atau minimal keluarga itu sendiri. Oleh karena itu dituntut tanggung jawab dan etika yang 
maksimal dalam menentukan kebijakan terkait lingkungan kerja.

Adanya CSR (corporate social responsibility) merupakan salah satu keharusan bagi suatu perusahaan. Hal itu sebagai wujud dari tanggung jawab pihak perusahaan. Tanggung jawab sangat terkait dengan hak dan kewajiban yang pada akhirnya menimbulkan kesadaran sosial (Buchari A., Donni. J, 2009 : 178). Oleh islam hal ini sangatlah dianjurkan agar mampu mengendalikan diri dari suatu tindakan melampaui batas kewajaran dan kemanusiaan.

Dalam ekonomi, pelaku usaha, perusahaan atau badan usaha lain bertanggung jawab kepada Allah atas perbuatannya yang meliputi ; tanggung jawab kelembagaan, sosial dan hukum. Dalam tanggung jawab sosial, seseorang (secara moral) harus mampu mempertanggung jawabkan perbuatannya terhadap masyarakat apabila melakukan perbuatan tercela (Faisal Badroen, dkk., 2006 : 188).

Beberapa konsep kebijakan bagi suatu perusahaan terkait dengan tanggung jawab dan lingkungan kerja dipaparkan oleh Imam Ghazali dalam kitabnya bidayah al-hidayah. Pemaparan ini dikutip oleh A. Bachrul Ulum, (2007) bahwa,

"janganlah kamu meremehkan budak perempuanmu dan budak laki-lakimu, maka kewibawaanmu akan jatuh dari hati mereka. Pikirkanlah alasnanmu dan jangan banyak memberi isyarat dengan tanganmu. Dan jangan jadikan hartamu lebih mulia daripada kehormatanmu."

Artinya, dalam menjalankan usaha, perusahaan juga harus memperhatikan mashlahah pekerja, dengan beretika yang baik, memberikan hak-hak pekerja yang meliputi, hak mendapat gaji, hak mendapat istirahat, hak mendapat jaminan sosial, dan sebagainya seperti yang diterangkan dalam UU No. 13 Tahun
2003 tentang Ketenagakerjaan. Penerapan jam kerja, aturan, dan lingkungan kerja wanita sama dengan laki-laki merupakan salah satu pelanggaran dari norma dan aturan agama maupun undang-undang.

Pelanggaran atas hal itu merupakan suatu kerusakan yang fatal akibatnya. Sebab, akan saling merugikan. Larangan ini tertuang dalam Hadits riwayat Ibn Majah, Daruqutni,

"Dari Abu sa'id, Sa'ad bin Malik bin Sinan Al-Khudri R.A, sesungguhnya Rasulullah SAW telah bersabda ; “janganlah engkau membahayakan dan saling merugikan”. (HR.Ibn Majah, Daruquthni)

Penjelasan hadist tersebut menurut, Ibnu Daqiqil 'Ied, (2013), bahwa perbuatan merugikan orang lain merupakan perbuatan dzalim, dan perbuatan dzalim ialah haram. Seperti yang telah diterangkan dalam Hadist Abu Dzar,

"Wahai hamba-Ku, sesungguhnya Aku telah mengharamkan diriku berbuat dzalim dan menjadikannya haram jug a diantara kamu, maka janganlah berbuat dzalim.” (HR. Muslim)

Selanjutnya, masih dalam penjelasan Ibnu Daqiqil 'Ied, (2013) dia juga mengutip pernyataan $\mathrm{Al}$ Mahasini yang berkata,

"Bahwa yang dimaksud dengan merugikan adalah melakukan hal yang bermanfaat bagi dirinya, tetapi menyebabkan orang lain mendapat madharat.”

Begitulah pemaparan tentang pengelolaan perusahaan yangterkait dengan hajat orang banyak (lingkungan kerja). Dapat disimpulkan bahwa perusahaan dilarang memeras hak-hak tenaga kerjanya terutama wanita dengan tidak memberi waktu untuk berinteraksi dengan keluarganya.

Lingkungan kerja bagi wanita harus ditata sebaik mungkin sehingga dalam menjalankan kodratnya, wanita benar-benar mendapatkan hak 
dan kewajibannya sebagai seorang ibu rumah tangga maupun pekerja. Menurut Risa Fadhila, (2015), kebijakan tersebut bisa meliputi aturan jam kerja dan cuti yang memungkinkan wanita untuk menyusui, dan berinteraksi dengan keluarga. Selain itu, perusahaan dianjurkan untuk melengkapi diri dengan fasilitas tempat menyusui, dan penitipan anak yang layak dan nyaman.

Kebijakan ini bagi perusahaan juga akan mendapatkan keuntungan berupa kinerja yang maksimal dari pekerja perempuan. Sebab, perempuan tidak lagi mencemaskan kondisi (kewajiban) rumahan. Adanya hal ini juga mendorong perekonomian negara. Sebab, peran perempuan dalam pertumbuhan perekonomian nasional sangat besar. (Suara Merdeka, 28 Agustus 2015 : 23).

\section{Penutup}

Adanya gender seharusnya tidak menjadikan perempuan justru terhina secara bathiniah dengan lingkungan kerja yang tidak manusiawi. Dalam islam, gender dipandang sebagai kesamaan hak untuk beramal saleh semata. Yaitu hak untuk mendapat pendidikan dan pekerjaan yang layak. Bukan pekerjaan yang sama dengan laki-laki.

Secara kodrati laki-laki dan wanita mempunyai tugas dan misi masing-masing. Ibarat perusahaan, laki-laki diciptakan sebagai investor, sedangkan perempuan memiliki tugas yang lebih kompleks, yaitu sebagai manager. Sedangkan anak berkedudukan sebagai produk yang harus dikelola secara maksimal agar mempunyai nilai guna lebih dan bermanfaat.

Oleh karena itu, menciptakan lingkungan kerja yang ramah perempuan dan anak merupakan langkah wajib. Sebab, hal ini menjadi kunci utama dalam mewujudkan pertumbuhan ekonomi yang berkelanjutan tanpa mengesampingkan hak-hak individu. Penerapan kebijakan seperti diatas juga tidak akan membuat perusahaan menjadi rugi.

Sebab, hal itu justru akan menaikkan citra perusahaan dimata masyarakat. Perusahaan juga akan mendapatkan kualitas pekerja yang diharapkan. Hal itu juga akan mendorong semangat dan produktivitas pekerja, sehingga target yang telah ditentukan oleh suatu perusahaan akan berjalan maksimal.

\section{Daftar Pustaka}

Ulum, A. Bachrul. 2007. Etika Bergaul Makhluq dengan Sang Khalik,Cet.I, Ampel Mulia : Surabaya

Badrudin. 2014. Dasar-Dasar Manajemen, Cet.I, Alfabeta : Bandung

Buchari A. dan Donni J., 2009. Manajemen Bisnis Syariah, Cet.I, Alfabeta : Bandung

Coleman. 1976. Abnormal I'syelogy and Modern Life, Illonis : Scott. Foresman \& Co

Desmita. 2013. Psikologi Perkembangan, Cet.VIII, PT Remaja Rosdakarya : Bandung

Badroen, Faisal. dkk., 2006. Etika Bisnis dalam Islam, Cet.I, Kencana : Jakarta

Daqiqil, Ibnu., 2013. Syarah Hadist Arba'in Imam Nawawi, Cet.I, Hikam Pustaka : Jogjakarta

Ghufron, M. Nur. 2013. Makna Karir Bagi Wanita Karir, dalam Prosiding Seminar Nasional Gender dan Islam, Cet.I, PSG STAIN Kudus : Kudus

Taubah, Mufatihatut. 2010. Eksistensi Wanita Dalam Kehidupan Pertama (Postnatal) Manusia, dalam Jurnal Islam Empirik Vol. 3 No. 1 Januari-Juni 2010, P3M STAIN Kudus : Kudus 
Jurnal Harkat : Media Komunikasi Gender, 14 (2), 2018

Suhadi. 2010. Respon Islam Terhadap Fadhila, Risa. 2015. Mempertegas Hak Ibu Feminisme, dalam Jurnal Studi Gender Menyusui, dalam Koran Harian Suara Palastren Vol. 3 No. 1 Juli 2010, Cet.I, PSG STAIN Kudus : Kudus

Merdeka, 28 Agustus 2015.

Supriyadi. 2015. Dasar-Dasar Hukum Perdata di Indonesia, Cet.I, CV. Kiara Science : Kudus. 